\title{
Knowledge Management in the Network Mode: The Case of Private Equity
}

\author{
Britta Klagge and Carsten Peter \\ Britta Klagge, Institute of Geography, University of Osnabrück, Germany (bklagge@uos.de) \\ Carsten Peter, Institute of Geography, University of Osnabrück, Germany (cpeter@uos.de)
}

\begin{abstract}
There has been an ongoing debate on the changing geographical organization of the financial sector and the decreasing importance of regional financial centres. Our contribution explores a fresh perspective on this issue by looking at knowledge and risk management in different parts of the financial sector with an empirical focus on private equity in Germany. The argument we put forward is that the ways in which providers of finance manage knowledge and risk shape their organizational and geographical structure. In our analytical framework we distinguish between three ideal-type modes of knowledge management: the relationship, the data and the network mode. These modes differ in the types of knowledge exchanged, the actors involved and in the role and nature of relevant contacts and relationships. The shift from relationship to data mode in credit provision in Germany serves an example of how a new mode of knowledge management is associated with changes in the geographical organization of financial actors and activities. To illustrate the network mode we then focus on knowledge management in private equity in Germany, which involves a variety of different actors and links both regional and interregional networks. Our empirical research shows that the resulting organizational and geographical structures are rather complex and have nodes in regional financial centres. While these centres benefit from private equity activities, their chances for re-vitalization and a re-regionalization of financial expertise on the basis of private equity are nonetheless limited. So far, Munich seems to be the (only) one location where private equity - cross-fertilized by other local financial actors - has initiated a self-supported development which strengthens Munich as a financial centre.
\end{abstract}

Keywords: knowledge management and transfer, networks, financial centres, private equity

\section{Introduction}

Bank finance and especially the provision of credit to small and medium-sized enterprises (SMEs) in western countries have been characterized by a shift from trustful relationships and frequent interaction between bank managers and their clients to standardized procedures and arms' length relationships. Although there are national differences in the extent and specificity of this development, this shift is generally associated with a concentration of banks' decision-making capacities and infrastructures (Degryse and Ongena 2005). This has led to and supported their geographical centralization in national financial centres, whereas regional financial centres have lost in importance. It is in this context that the regionalized organization of private equity providers in Germany, but also other countries (Klagge and Martin 2005), along with the reliance on regional financial centres in their networks is particularly interesting. In our paper we will empirically explore the reasons for this structure by focussing on the ways in which private equity (PE) firms manage knowledge and risk. We will show that they do so in a way very different from traditional bank business, leading to what we 
call the network mode of knowledge management - in contrast to the relationship and the data mode which characterize credit provision by banks.

The argument we put forward in this paper is that the ways in which finance providers manage knowledge and risk shape their organizational and geographical structure. Our argument is based on the importance of knowledge in the provision of capital, here referring to financial capital (i.e. 'liquid' money capital or, brief, finance). The provision of finance is and has always been closely related to the creation, transfer and use of knowledge, e.g., on credit or other investment opportunities and the associated risk (Grote et al. 2002, Lo 2003). This means that - contrary to the general assumptions of neoclassical theory - there is no transparent or perfect information in the world of finance (Akerlof 1970). Rather the very core of the provision of finance is managing and dealing successfully with both codified and tacit knowledge, knowledge asymmetries and the associated uncertainty and risk (Clark and O'Connor 1997).

In our paper we suggest that there are different modes of how finance providers deal with this uncertain situation. We first introduce the relationship and the data mode of knowledge management and explain how the first is associated with an organizationally and geographically decentralized structure whereas the latter supports centralization. We illustrate how there has been a shift from the first to the latter in credit provision to SMEs and how this shift has indeed led to centralization in the banking sector. We then focus on the network mode which has been emerging in the provision of private equity. In contrast to the relationship and the data mode, which are characterized by bilateral relationships of banks with their clients, the network mode relies on the integration of third-party actors. This mode therefore constitutes a different approach to knowledge management which is more complex, also geographically.

The research question to be answered in this paper is how the network mode of knowledge management shapes the geographical organization of private equity provision. By relying on networks of varying geographical scopes with nodes in regional financial centres, the private equity sector seems to support a revitalization of these centres. We will explore this proposition by looking at knowledge management in Germany's private equity sector. Germany provides a good case study for this question as regional financial centres in Germany used to be important locations for finance providers and have only recently lost their significance. Finally, we will summarize our results and discuss possible implications for the German financial system more generally.

\section{Modes of Knowledge Management in Credit Provision: From Relationship to Data Mode}

Traditionally, credit provision to SMEs has relied on comprehensive, including tacit, knowledge on firms, their management resources and innovation potential, which the bank gathered in close relationships with their clients. This has involved frequent interaction and is based on personal relationships which are built on face-to-face contacts as well as through being part of the same social context. We call this traditional approach to deal with knowledge asymmetry and the associated risk relationship mode because it is predicated upon engagement in trustful relationships in which various types of knowledge are shared, transferred and jointly created (Table 1). In Germany, most firms even used to have one main bank with which they would conduct most of their financial affairs, the so-called house bank ('Hausbank') which acted as financier and - in some cases - advisor (Klagge 1995, Pieper 2005). 
The relationship mode is associated with a rather decentralized organizational and geographical structure of banks. Local branches serve local clients, which facilitates face-to-face contacts and the development of trustful relationships and thus the exchange of tacit knowledge. Credit decisions are taken locally or regionally thus ensuring the consideration of different types of knowledge on firms and their context conditions. While this case-specific and somewhat 'subjective' decision-making provides some obvious advantages, it also runs the danger of nepotism and lock-in situations. In addition, it is also rather labour- and therefore cost-intensive. Especially the latter point, in combination with broader structural changes in the financial sector, has led to a shift away from the relationship mode in credit provision to SMEs.

Table 1: Modes of Knowledge Management in the Provision of Credit to SMEs

\begin{tabular}{|c|c|c|}
\hline & Relationship mode & Data mode \\
\hline Knowledge & $\begin{array}{l}\text { Comprehensive, including tacit } \\
\text { knowledge }\end{array}$ & $\begin{array}{l}\text { Codified knowledge, esp. numerical } \\
\text { data, (e.g., balance sheets) }\end{array}$ \\
\hline Contacts and relationships & $\begin{array}{l}\text { Frequent interaction, formal \& } \\
\text { informal contact (face-to-face!), } \\
\text { trustful relationships, often } \\
\text { common social context }\end{array}$ & $\begin{array}{l}\text { Purpose-driven, formal contact, not } \\
\text { necessarily face-to-face, governed } \\
\text { by formal requirements }\end{array}$ \\
\hline $\begin{array}{l}\text { Analysis and decision-making } \\
\text { procedures }\end{array}$ & $\begin{array}{l}\text { Case-specific, individual, } \\
\text { 'subjective' }\end{array}$ & $\begin{array}{l}\text { Standardized, computerized, } \\
\text { 'objective' }\end{array}$ \\
\hline Organization and geography & $\begin{array}{l}\text { Decentralized competence } \\
\text { structure with important role for } \\
\text { local and regional outlets }\end{array}$ & $\begin{array}{l}\text { Potential for concentration and } \\
\text { centralization of competences and } \\
\text { expertise }\end{array}$ \\
\hline Positive side effects & $\begin{array}{l}\text { Exchange \& joint creation of } \\
\text { various types of knowledge }\end{array}$ & $\begin{array}{l}\text { Standardized data collection allows } \\
\text { for benchmark and comparative } \\
\text { analyses }\end{array}$ \\
\hline Dangers and problems & $\begin{array}{l}\text { Nepotism, lock-in, labour-and } \\
\text { therefore cost-intensive }\end{array}$ & $\begin{array}{l}\text { Neglect of human factor (e.g., } \\
\text { management resources), context and } \\
\text { innovations }\end{array}$ \\
\hline
\end{tabular}

In the last two decades new technologies, regulation and other developments in the financial sector have greatly increased national as well as international competition in the financial sector and especially for banks (Marshall et al. 1992, Klagge 1995, Schamp 1999, Pollard 2003, Klagge and Zimmermann 2004, Pieper 2005). This has led to an ongoing search for economies of scale in order to cut costs and resulted in new ways of delivering financial services, especially credit. Based on the opportunities provided by new IC technologies and supported by new regulation (Basle 2), the management of knowledge and risk in credit provision has to a large degree been standardized resulting in what we call the data mode (Table 1).

Contrary to the relationship mode, the data mode is based on the provision of certain data by firms which the banks then use to decide on whether making finance available or not. The data usually takes the form of balance sheet and other numerical data, i.e. it is restricted to codified knowledge which might be secret, but is easily transferable. In this mode, contact between the firm as client and the decision makers in the bank is mainly reduced to the transfer of data and capital, and face-to-face contacts 
are not important. Context conditions, management resources and the innovative capacities tend to be neglected, while at the same the danger of nepotism is small. Due to the standardized way in which the data are processed and evaluated there is a high potential for computerization and centralization - and thus for cutting infrastructure and labour costs as well as for benchmark and comparative analyses.

The shift from relationship to data mode has resulted in profound changes in the organizational and geographical structure of banking and finance more generally. These include the concentration and centralization of competences and functions in national headquarters as well as the development of structures based on formalized procedures (Clark and Thrift 2003). The most visible result of this development is the downgrading or closing of bank branches. This process has been accompanied by the centralization of decision-making and thus the withdrawal of financial expertise from the regions and from regional financial centres.

The erosion of the decentralized financial system associated with these organizational changes in bank finance has altered the conditions of external finance for SMEs. In the past, they accessed finance with the help of competent bank agents who supported them in meeting banks' requirements and in their financial affairs - and potentially even beyond those. Now, they are increasingly left alone - or with bank staff that is less competent and has no decision-making power - in meeting formal and rather bureaucratic data requirements. In addition, and as a consequence of Basle 2, the conditions for getting credit have tightened. This means that many SMEs, especially those with low equity ratios (like start-ups), have difficulty in accessing finance or can do so only when accepting higher interest rates (Lichtblau and Utzig 2002, KfW Bankengruppe 2003). In this situation, private equity has been advocated as a solution which not only provides much needed capital, but would also help to increase equity ratios and hence the chances to receive bank credit.

\section{Private Equity as an Alternative Form of Financing: Knowledge Management in the Network Mode}

Private equity firms invest financial capital in non-listed companies, and mainly focus on companies in very dynamic or innovative sectors of the economy. One of the reasons why private equity financing has a rather limited scope with respect to its target, i.e. its portfolio companies, lies in the specific risk that is associated with it. Private equity is a form of finance without collateral and is therefore much more risky than e.g., credit finance (Schefczyk 2000, Smith and Florida 2000). While on one hand it allows very high returns on investment in case a company does well, an investment could on the other hand be totally lost in case the company goes bust. This poses specific challenges for private equity firms as providers of private equity with regard to the management of knowledge and risk (Zook 2004). In order to empirically analyze how private equity firms manage knowledge and risk we conducted expert interviews with 28 professionals in private equity firms in Munich, Hamburg, Frankfurt and Hannover, most of them partners or senior investment managers. Furthermore, we interviewed 21 leading representatives of service providers and other organizations related to private equity in Munich, Hamburg, Frankfurt and Berlin such as banks, law and accountancy firms, business associations and incubators. Our interviewees were found by using business directories, yearbooks, webpages as well as through recommendations by business associations and already interviewed experts. The most important issues covered in 
these interviews were private equity firms' knowledge management and network strategies.

\section{Private Equity Firm and Portfolio Company: A Connection Governed by the Relationship Mode}

One important way of how private equity firms manage the knowledge asymmetries and the associated risk in the private equity business is to closely interact with their portfolio firms before and during their investment (Schefczyk 2000, for a view which focuses on power in investment relationships see Jones and Search 2009). By thoroughly preparing the deal and checking out the company in the so-called due diligence, they try to assess risks and opportunities and do so in collaboration with external partners. After the investment decision, most of them monitor the portfolio companies closely. Furthermore they support their development by providing various types of knowledge inputs and often also by actively participating in senior management or being represented on the supervisory board (Gompers and Lerner 2001). The CEO of a Munich-based private equity firms explains:

"We receive regular reportings and we are frequently on the ground [in the portfolio-company]. We define us as strategic sparring partners, like yesterday evening when we discussed with the executives how we could modify the management structure."

Geographical proximity, but also other types of proximity (Jones and Search 2009) facilitate such close relationships. Therefore, private equity firms and their portfolio companies tend to be located rather near to each other, often in the same region or within two to three hours travel time (Martin et al. 2005, Zook 2004). This corresponds with the rather decentralized geographical patterns of private equity firms. In the case of Germany, we find an extremely decentralized pattern with significant concentrations in regional financial centres (Munich 39, Frankfurt 38, Hamburg 23, Berlin 16, Düsseldorf 12 plus 92 in other locations, many of them with public participation, BVK 2008).

The evidence provided so far suggests that the provision of private equity is governed by the relationship mode of knowledge management: There is a reliance on frequent interaction, face-to-face contacts and trustful relationships and an important role for the exchange and development of various types of knowledge in order to minimize risk - and all this resulting in a rather decentralized organizational and geographical structure. However, in order to fully understand private equity firms' approach to the management of knowledge and risk, one has to look beyond the bilateral relationship of private equity firms with their portfolio companies.

\section{The Network Mode: External Knowledge Inputs and Active Development of Knowledge Networks}

An analysis of the private equity process shows that private equity firms' strategy to knowledge management relies on the production and exchange of knowledge with various external partners (Klagge and Peter 2009). This way of knowledge management is an example of what we call the network mode. It exhibits a relatively complex organizational and geographical structure as will be exemplified by looking more closely at knowledge networks of private equity firms in Germany. 
Based on a value chain analysis of private equity (Schefczyk 2000, Achleitner 2001), Figure 1 illustrates how different types of external partners are involved in various stages of the private equity process. Additional partners not depicted in figure 8.1 include investors, portfolio companies and other private equity firms. All these partners and the relationships with them constitute networks of varying geographical scales. Some partners of private equity firms are regional, i.e. they are located in the same city or sometimes even in the same street, while other partners are national or international. The character of relationships between private equity firms and their partners (e.g., formal-informal, frequency of contact) varies according to the stage and the types of knowledge inputs. Especially the more informal interaction is often based on mutual recognition and trust, which are facilitated by having done business together, by a shared professional background and also by private contacts.

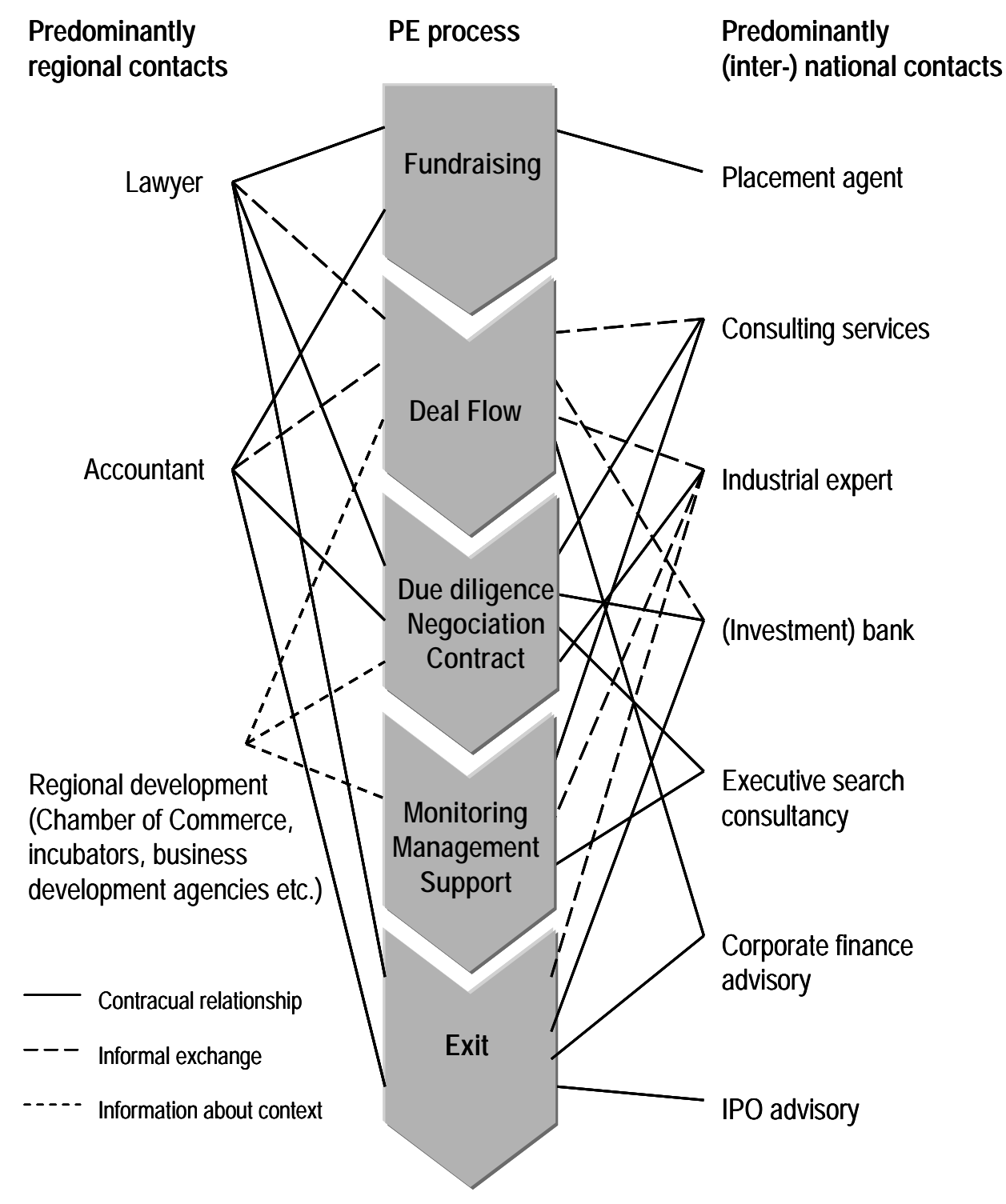

Figure 1: External partners and their relationships with private equity (PE) firms along the PE value chain 
Regional partners of private equity firms include not only portfolio companies, but also certain service providers, regional development agencies as well as other private equity firms. The relationships with lawyers and accountants are of special importance and can be characterized as being governed by the relationship mode. Private equity firms cooperate regularly with the same lawyer or accountant in different stages of the same deal as well as in different deals. Their relationships are close and involve frequent contact, often face-to-face, as the partners discuss sensitive issues and exchange ideas trustfully. Spatial proximity supports this exchange of confidential knowledge as the CEO of a private equity firm in Hamburg explains:

"Even within walking distance, that's important. When you are working together in a project, you may sit together for five days in one company in one room ... You need short distances then. It is impossible to have somebody in Munich.”

Apart from formal relationships based on mandates and contracts, private equity firms are in contact with their lawyers and accounts also in an informal and reciprocal way. They continuously exchange knowledge about companies and the regional economy informally, and this helps to improve private equity firms' deal flow, as the CEO of a private equity firm in Frankfurt explains:

"It is an interplay of giving and receiving. We are looking for targets, they are looking for mandates.”

Other regional actors are not or only marginally involved in the private equity process itself, but they are seen as partners that help to generate deal flow by providing knowledge on the regional economy and on potential portfolio companies. Private equity firms actively develop networks with and personal ties to representatives of chambers of commerce (COC), incubators, business development agencies, business associations, research institutes, but also interesting companies as well as other private equity firms in the region. Membership in regional organizations and taking part in regional events is an important strategy to develop regional networks, as the representative of the Hamburg branch of an international private equity firm explains:

"Yes, they [the COC in Hamburg] are helpful insofar as one is member of a COC committee ... the COC consists of a network of important people, also and especially in Hamburg. Those people are in the COC ... sometimes I am sitting in a committee and there are also all CEOs of banks, insurance companies and private equity firms in Hamburg - an illustrious club, a network, which provides us with more cases to work on..."

In addition to regional partnerships and networks, private equity firms strategically build up contacts with national or even international experts to attain specific knowledge inputs and other resources (e.g., capital). The relationships with these partners are based on contracts which specify their contribution to specific cases, but they sometimes also provide informal inputs in other stages (Figure 1). For (case-) specific inputs, private equity firms always look for the best available expert or partner. To find them they use their existing contacts and networks which they constantly extend by participating in conferences, fairs and other events. Thus, the selection of experts is first and foremost dependent on the specific input rather than on accessibility via spatial proximity, as an investment manager in Munich explains: 
"Regarding the market due diligence, we have two advisors we are working with. One is in Munich, the other one in Frankfurt. Spatial proximity is not really necessary here ... We will not select an advisor because he is located in Munich. It should be someone we consider to be suitable to advise us."

Whereas consultants and other advisors are mostly located in larger cities - like Frankfurt, Munich, Düsseldorf and Hamburg -, industrial experts can be found anywhere. Most of them are located close to their primary or former place of occupation as CEOs, managers, entrepreneurs or scientists. The CEO of a private equity firm in Munich explains:

"They [industrial experts] can sit anywhere once you have the contact ... For example for laser technology we had contacts in Aachen."

Another category of private equity firms' partners are financial experts. They include placement agents, corporate finance and IPO (initial public offering) advisors as well as (investment) banks and are mostly based in international financial centres like Frankfurt and London. However, there are also quite a few corporate finance advisors and banks with regional branches or even head offices in Munich. These offices mainly serve local clients including private equity firms - thus reinforcing Munich's position as the largest location of private equity firms in Germany.

Other private equity firms also play an important role in a private equity firm's knowledge and risk management. The relationships among private equity firms range from pure competition over informal mutual consultation to syndication, i.e. the coinvestment in a portfolio company. Syndication is used as a mechanism to share the risk inherent especially in start-up funding and also to overcome geographical distance (Fritsch and Schilder 2006, Lerner 1994). It supports private equity firms in diversifying their portfolio and in learning from each other. In particular, they engage in syndication in order to get access to their partners' network and knowledge resources (Sorenson and Stuart 2001). Overall, managing the relationships with other private equity firms is an issue of balancing cooperation and competition as the CEO of a private equity firm in Hamburg explains:

"The famous networking, one knows each other. The [private equity] industry is characterized by the beautiful word co-opetition. One cooperates if possible, but one [also] fights each other [...]. We are jointly engaged in a company with other private equity firms and are fighting against each other about another deal. This is normal."

In summary, our empirical research shows that private equity firms identify and select strategically various external partners in different locations. They actively develop networks and personal ties by

- membership in regional, professional and industry-specific associations and committees (of associations, COC, (local) state),

- participation in conferences, fairs, events, e.g., on private equity, technology (transfer) and SME finance, and in meetings of associations, committees etc. and

- doing business together with banks, service suppliers and other private equity firms (syndication). 
Using such strategies private equity firms consciously acknowledge the role of networks and regard them as extremely important for doing business successfully. Their networks provide indispensable knowledge inputs in all stages of the private equity process and help to manage risk and avoid lock-ins. They are based on various types of relationships with a wide range of network partners who differ in terms of professional and also geographical backgrounds.

\section{Regional Financial Centres as Nodes in Private Equity Knowledge Networks: A Chance for their Revitalization?}

The integration into both regional and interregional networks is an actively pursued strategy of private equity firms in Germany and at the core of their approach to cope with risk and uncertainty. Regional financial centres are not only the locational base for private equity firms, but also constitute nodes in their knowledge management strategies and networks. The overall role of regional networks in these centres, however, is somewhat restricted. First and foremost, regional networks provide private equity firms with knowledge on the regional economy. Hence, they are especially important for generating deal flow, for selecting and monitoring portfolio companies. Trust-building in these regional networks is supported by face-to-face contact, by common regional context and by doing business together.

In addition to knowledge inputs on the regional economy, regional financial centres exhibit some, but not necessarily all types of service providers important in the private equity process. Lawyers and accountants who provide very sensitive, but rather standardized inputs are generally local partners of private equity firms. In contrast, specialized knowledge inputs on technologies, industries and markets as well as financial services related to fundraising and exit are sourced nationally or even internationally. Hence, private equity firms and their regional networks do strengthen business activities in regional financial centres. However, they do not automatically support a reregionalization of financial expertise and thus a revitalization of regional financial centres. Overall, private equity therefore only offers limited potential to compensate for the loss of financial expertise due to the centralization of banking and credit provision.

Munich, which is the largest and most dynamic location for private equity firms and especially for start-up funding in Germany - and in addition is an important place for banking, insurance and asset management -, is an exceptional case. There is a very active local private equity scene, supported not only by specialized lawyers and accountants, but also by other, financial, management and technological, service providers in the region. Important reasons for this development include the economic dynamics in and around Munich, the good transport infrastructure and last but not least the high quality of life.

\section{Conclusions}

In our paper, we show that the ways in which finance providers manage knowledge and risk shape their organizational and geographical structure. We distinguish between three modes of knowledge management: the relationship, the data and the network mode. They differ in the types of knowledge exchanged, the actors involved and in the role and nature of relevant contacts and relationships. The shift from relationship to data mode in credit provision is an example of how a new mode of knowledge management is 
associated with changes in the geographical organization (here: centralization) of financial actors and activities.

The case of private equity in Germany illustrates how knowledge management in the network mode implies rather complex organizational and geographical structures. These structures link both regional and interregional networks and have nodes in regional financial centres. Although regional financial centres benefit from private equity activities, chances for their re-vitalization and a re-regionalization of financial expertise on the basis of private equity are nonetheless limited. So far, Munich seems to be the (only) one location where private equity - cross-fertilized by other local financial actors - has initiated a self-supported development which strengthens Munich as a financial centre.

For the future of the German financial systems, our results indicate a more tiered structure including elements of functional specialization: Frankfurt is and remains the only major international financial centre and dominates the national market in banking and stock exchange activities, while Munich plays a secondary role with a particular and also internationally recognized strength in private equity. Other regional financial centres mainly serve regional markets and will very likely continue to benefit from private equity business and its regional knowledge networks.

\section{Acknowledgements}

This paper is based on research funded by the German Science Foundation (DFG). The authors thank the DFG for its financial support. They are also grateful to two anonymous referees for their helpful comments.

\section{References}

Achleitner, A.K. 2001. Venture Capital, in Handbuch Finanzierung, edited by R. E. Breuer. Wiesbaden: Gabler, 513-529.

Akerlof, G.A. 1970. The market for 'lemons': Quality uncertainty and the market mechanism. The Quarterly Journal of Economics, 84(3), 488-500.

BVK - Bundesverband deutscher Kapitalbeteiligungsgesellschaften e.V. 2008. Mitgliederverzeichnis.

Available online at: http://www.bvkap.de/privateequity.php/cat/4/ title/Mitglieder [accessed: 14 June 2010].

Clark, G. and O'Connor, K. 1997. The informational content of financial products and the spatial structure of the global finance industry, in Spaces of Globalization, edited by K. Cox. New York, London: Guildford Press, 89-114.

Clark, G. and Thrift, N. 2003. FX risk in time and space: Managing dispersed. Knowledge in Global Finance, 2003(5).

Degryse, H. and Ongena, S. 2005. Distance, lending relationships, and competition. The Journal of Finance, 60(1), 231-266.

Fritsch, M. and Schilder, D. 2006. Is Venture Capital a Regional Business? The Role of Syndication. Freiberg Working Papers 2006(9). Freiberg: Technical University Bergakademie Freiberg.

Gompers, P. and Lerner, J. 2001. The venture capital revolution. Journal of Economic Perspective, 15(2), 145-168.

Grote, M.H., Lo, V. and Harrschar-Ehrnborg, S. 2002. A value chain approach to financial centres. The case of Frankfurt. Tijdschrift voor Economische en Sociale Geografie, 93(4), 412-423. 
Jones, A. and Search, P. 2009. Proximity and power within investment relationships: The case of the UK private equity industry. Geoforum, 40(5), 809-819.

KfW Bankengruppe. 2003. Eigenkapital für den ,Breiten“ Mittelstand - Neue Wege und Instrumente. Available online at: www.kfw.de/DE_Home/Research/ onderthem68/Eigenkapit34/Eigenkapital_fuer_den_breiten_Mittelstand.pdf [accessed: 14 June 2010].

Klagge, B. 1995. Strukturwandel im Bankenwesen und regionalwirtschaftliche Implikationen. Konzeptionelle Ansätze und empirische Befunde. Erdkunde, 49(4), 285-304.

Klagge, B. and Martin, R. 2005. Decentralized versus centralized financial systems. Is there a case for local capital markets? Journal of Economic Geography, 5(4), 387-421.

Klagge, B. and Peter, C. 2009. Wissensmanagement in Netzwerken unterschiedlicher Reichweite. Das Beispiel des Private equity-Sektors in Deutschland. Zeitschrift für Wirtschaftsgeographie, 53(1-2), 69-88.

Klagge, B. and Zimmermann, N. 2004. Finanzstandort Deutschland: Banken und Versicherungen, in Nationalatlas Bundesrepublik Deutschland, Vol. 8: Unternehmen und Märkte, edited by Haas, H.-D., M. Heß, W. Klohn and H.-W. Windhorst. Heidelberg, Berlin: Spektrum, 60-61.

Lerner, J. 1994. The syndication of venture capital investments. Financial Management, 23(3), 16-27.

Lichtblau, K. and Utzig, S. 2002. Finanzierungs- und Kostenstruktur des deutschen Mittelstandes. Die Bank, 23(5), 326-331.

Lo, V. 2003. Wissensbasierte Netzwerke im Finanzsektor: Das Beispiel des Mergers \& Acquisitions-Geschäfts. Wiesbaden: Gabler.

Marshall, N., Gentle, C. J. S., Raybould, S. and Coombes, M. 1992. Regulatory change, corporate restructuring and the spatial development of the British financial sector. Regional Studies, 26(5), 453-467.

Martin, R., Berndt, C., Klagge, B. and Sunley, P. 2005. Spatial proximity effects and regional equity gaps in the venture capital market: Evidence from Germany and the UK. Environment and Planning A, 37(7), 1207-1231.

Pieper, C. 2005. Banken im Umbruch. Münster: Lit.

Pollard, J. 2003. Small firm finance and Economic Geography. Journal of Economic Geography, 3(4), 429-452.

Schamp, E.W. 1999. The System of German financial centres at the crossroads: From national to European scale, in Cities in Perspective I: Economy, Planning and the Environment, edited by Wever, E. Assen: Van Gorcum, 83-98.

Schefczyk, M. 2000. Finanzieren mit Venture Capital - Grundlagen für Investoren, Finanzintermediäre, Unternehmer und Wissenschaftler. Stuttgart: SchäfferPoeschel.

Smith, D.F. and Florida, R. 2000, Venture capital's role in regional innovation systems: Historical perspective and recent evidence, in Regional Innovation, Knowledge and Global Change, edited by Acs, Z. J. London: Pinter, 205-230.

Sorensen, O. and Stuart, T.E. 2001. Syndication networks and the spatial distribution of venture capital investments. American Journal of Sociology, 106(6), 1546-1588.

Zook, M.A. 2004. The knowledge brokers: Venture capitalists, tacit knowledge and regional development. International Journal of Urban and Regional Research, 28(3), 621-641. 